\title{
Economic analysis of coronary artery bypass grafting with minimal versus conventional extracorporeal circulation
}

\author{
K Anastasiadis $^{1 *}$, V Fragoulakis ${ }^{2}$, P Antonitsis ${ }^{1}$, N Maniadakis $^{2}$ \\ From 23rd World Congress of the World Society of Cardio-Thoracic Surgeons \\ Split, Croatia. 12-15 September 2013
}

\section{Background}

This study aims to develop a methodological framework for the comparative economic evaluation between Minimal Extracorporeal Circulation (MECC) versus conventional Extracorporeal Circulation (CECC) in patients undergoing coronary artery bypass grafting (CABG) in different healthcare systems. In addition, the scope is to evaluate the cost-effectiveness ratio of alternative comparators in the healthcare setting of Greece, Germany, the Netherlands and Switzerland.

\section{Methods}

The effectiveness data utilized were derived from a recent meta-analysis which incorporated 24 randomized clinical trials. Total therapy cost per patient reflects all resources expensed in delivery of therapy and the management of any adverse events, including drugs, diagnostics tests, materials, devices, blood units, the utilization of operating theaters, intensive care units and wards. Perioperative mortality was used as the primary health outcome to estimate life years gained in treatment arms. Bias-corrected uncertainty intervals were calculated using the percentile method of non-parametric Monte-Carlo simulation.

\section{Results}

The MECC circuit was more expensive than CECC, with a difference ranging from $€ 180$ to $€ 600$ depending on the country. However, in terms of total therapy cost per patient the comparison favoured MECC in all countries. Specifically it was associated with a reduction of $€ 789$ in Greece, $€ 511$ in Germany, $€ 2,343$ in the

\footnotetext{
* Correspondence: anastasiadisk@hotmail.com

'Department of Cardiothoracic Surgery, AHEPA University Hospital,

Thessaloniki, Greece

Full list of author information is available at the end of the article
}

Netherlands and $€ 1,141$ in Switzerland. In terms of effectiveness, the total life-years gained were slightly higher in favor of MECC.

\section{Conclusions}

Surgery with MECC may be dominant (lower cost and higher effectiveness) compared to CECC in coronary revascularization procedures and therefore it represents an attractive new option relative to conventional extracorporeal circulation for CABG.

\section{Authors' details}

'Department of Cardiothoracic Surgery, AHEPA University Hospital, Thessaloniki, Greece. ${ }^{2}$ Department of Health Services Organization \& Management, National School of Public Health, Athens, Greece.

Published: 11 September 2013

doi:10.1186/1749-8090-8-S1-0166

Cite this article as: Anastasiadis et al:: Economic analysis of coronary artery bypass grafting with minimal versus conventional extracorporeal circulation. Journal of Cardiothoracic Surgery 2013 8(Suppl 1):0166.

Submit your next manuscript to BioMed Central and take full advantage of:

- Convenient online submission

- Thorough peer review

- No space constraints or color figure charges

- Immediate publication on acceptance

- Inclusion in PubMed, CAS, Scopus and Google Scholar

- Research which is freely available for redistribution 